Please do not remove this page

RMIT

UNIVERSITY

\title{
'My parents came here with nothing and they wanted us to achieve': Italian Australians and school success
}

Miller, Pavla

https://researchrepository.rmit.edu.au/esploro/outputs/9921858718701341/filesAndLinks?institution=61RMIT_INST\&index=null

Miller, P. (2007). "My parents came here with nothing and they wanted us to achieve": Italian Australians and school success. In The Death of the Comprehensive High School?: Historical, Contemporary, and Comparative Perspectives (pp. 185-198). Palgrave-Macmillan.

https://researchrepository.rmit.edu.au/discovery/fulldisplay/alma9921858718701341/61RMIT_INST:Resea rchRepository

Document Version: Published Version

Repository homepage: https://researchrepository.rmit.edu.au

(C) 2007 Palgrave MacMillan

Downloaded On 2023/04/26 19:16:10 +1000 
-William J. Reese, Professor of F.ducational Policy Studies and History.

University of Wisconsin, Madison and author of History, Education, and the Schools

This is a fascinating book, providing manifold insights into important issues of educational policy and its consequences."

-Miriam Ben-Peretz, Professor Emeritus, Faculty of Education, University of Haifa and Visiting Professor, Institute of Education, University of I.ondon

"The authors make a strong case that both the past accomplishments and present perils of the comprehensive high school are examgerated, noting that its promise of equal education often turned into the reality of tracking by class and race, and that its supposed dernise in the 21 st century may actually represent a rehirth of the comprehensive ideal in new forms."

-David F. Labaree, Prolessor and Associate Dean for Student Affairs, School of Education, Stanford Lniversity

BARRY M. FRANKLIN is Professor of Education and Adjunct Professor of History, Utah State University

GARY MCCULLOCH is the Brian Simon Professor of the History of Education, Institute of Education, University of London and the author of Cyril Norwood and the Ideal of Secondary Education and Documentary Research in Education. History and the Social Sciences

Secondary Education in a Changing World

Series Editors: Barry M. Franklin and Gary McCulloch ca. 1908, courtesy of Iferberl M. Klicbard.

Jacket design: Ann Wcinstock

\section{The Death of}

\section{the Comprehensive}

\section{High School?}

HISTORICAL, CONTEMPORARY, AND COMPARATIVE PERSPECTIVES

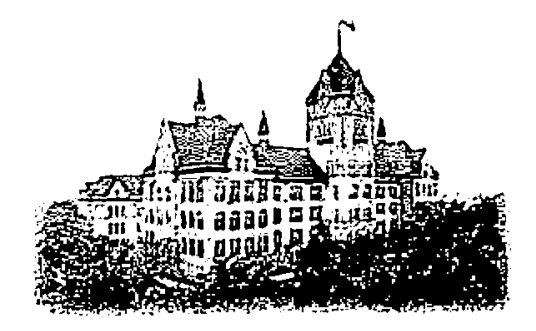

Edited by Barry M. Franklin and Gary McCulloch 
First published in 2007 by

175 Fifth Avenue. New York, N.Y. 10010 and

\section{Contents}

Houndmills, Basingstoke, Hampshire, England RG2 1 6XS

Companies and representatives throughout the world.

PALCRAVE MACMILLAN is the global academic imprint of the Palgrave

Macmillan division of St Martin's Press, LLC and of Palgrave Macmillan Ltd.

Macmillan ${ }^{\otimes}$ is a registered trademark in the United States, United Kingdom

and other countries. Palgrave is a registered trademark in the European

Union and other countries.

ISBN-13: 978-1-4039-7769-4

ISEN-10: 1-4039-7769-0

Library of Congress Cataloging-in-Publication Data

The death of the comprehensive high school? : historical, contemporary and comparative perspectives / Barry M. Franklin and Gary McCulloch. editors.

p. $\mathrm{cm}$.- (Secondary education in a changing world)

Includes bibliographical references and index.

ISBN 1-4039-7769-0 (alk. paper)

1. Comprehensive high schools-Cross-cultural studies. 2. Education Secondary-Cross-cultural studies. I. Franklin, Barry M. II. Mcculloch.

Gary. III. Series.

\section{7}

373.250973-de22

2007010723

A catalogue record for this book is available from the British Library

Design by Newgen Imaging Systerns ( $P$ ) Ltd., Chennai, India.

First edition: December 2007

10987654321

Printed in the United States of America.

\section{Introduction}

1 Introduction-The Death of the Comprehensive High School? Historical, Contemporary, and Comparative Perspecrives

Barry M. Franklin and Gary McCulloch

\section{Historical Perspectives}

2 Custodialism and Career Preparation in a Comprehensive High School, 1929-1942 Sevan G. Terzian

3 Education for All American Youth (1944): A Failed Attempt to Extend the Comprehensive High School Wayne J. Urban

4 The Comprehensive High School, Enrollment Expansion, and Inequality: The United States in the Postwar Era John L. Rury

\section{Contemporary Perspectives}

5 Breathing Life into Small School Reform: Advocating for Critical Care in Small Schools of Color Rene Antrop González and Anthony De Jeswis

6 Soul Making in the Comprehensive High School The Legacies of Frederick Wiseman's High School and High School II

Jose $R$ Rosario

7 The End of the Comprehensive High School? African American Support for Private School Vouchers Thomas C. Pedroni 


\section{Comparative Perspectives}

8 The Formation of Comprehensive Education: Scandinavian Variations

Susanne Wiborg

\section{Introduction}

Missing, Presumed Dead? What Happened to the

Comprehensive School in England and Wales? David Crook

10 The Comprehensive Ideal in New Zealand: Challenges and Prospecrs

Gregory Lee, Howard Lee, and Roger Openshaw

11 "My Parents Came Here with Nothing and

They Wanted Us to Achieve": Italian

Australians and School Success

Pavla Miller

Epilogue

12 Epilogue-The Future of the Comprehensive High School Gary McCulloch and Barry M. Franklin

Contributors

205

Index 
Tate, F. (1925). Investigation into certain aspects of post-primary education in New Zealand (Special report on educational subjects No. 16). Wellington: Government Printer.

Thom, A.H. (1950). The distriat high schouls of New Zealand. Wellington: New Zealand Council for Educational Research.

Thomson, A. (October 26, 2005). Schools told: Help strugglers. The New Zealand Herald, p. Al.

Walker, R. (1985). Cultural domination of Taha Maori: The potential for radical transformation. In J. Codd, R. Harker, and R. Nash (eds.), Political issues in New Zealand education (pp. 73-82). Palmerston North: Dunmore Press.

Whitehead, C. (1974). The Thomas report-A study in educational reform. New Zealand Joumal of Educational Studies 9 (1): 52-64.
Miller, P 2007, "My parents came here with nothing and they wanted us to achieve': Italian Australians and school success' in B. Franklin and G. McCulloch (ed.) The Death of the Comprehensive High School?: Historical, Contemporary, and Comparative Perspectives, Palgrave MacMillan, New York. USA, pp. 185-198.

\section{Chapter 11}

\section{"My Parents Came Here with Nothing and They Wanted Us to Achieve": Italian Australians and School Success}

\author{
Paula Miller
}

In Australia, as in other countries, the unfinished project of making high schools "comprehensive" is under attack. In the 1970 s, comprehensive schools were depicted as flawed but perfectible engines of democratic citizenship, neighborliness, equality of opportunity, and effective preparation for a diversity of productive lives. Today, national governments encourage market competition between schools, provide substantial subsidies to the private education sector, are skeptical about the worth of public institutions, and miserly with funding them. ${ }^{1}$ The competition for enrolments is a serious business for government schools. In the last 15 years, many have closed despite strong community support because their enrolments fell beyond what education departments saw as sustainable. In turn, and often reluctantly, parents in many regions and social groups are coming to see comprehensive schools as residual institutions for those unable or unwilling to send their children elsewhere. There is compelling evidence that these developments are actively and systematically contributing to social polarization. Yet, as in the past, schools do not simply "reproduce" patterns of privilege and subordination in the wider sociery. Some regions, schools, programs, and social groups do considerably better than expected, others do worse. To provide a sense of this uneven process, this chapter sets research on inequality and educational outcomes alongside the trajectory of one relatively successful working-class group. Drawing on the accounts of 
family life by three generations of Italian Australians in Melbourne, ${ }^{2}$ the chapter emphasizes the value of both systemic and "local" analyses.

After two decades of expansion and consolidation, Australia has one of the After two decan the strongest privace educational (OECD) countries: only Netherlands, Cooperation and Development (OECD) countries: only Netherlands Belgium, and Spain have larger proportion of junior secondary cnrolments in private schools. Importantly, both private and government contributions to the private education sector have outstripped rates of its enrolment to the private education sector have of private school enrolments at the growth. In 2000 , the average share of private school enrolments at the junior secondary level among OECD countries was 16.4 percent. In Justralia, at 30.9 percent, it was almost rwice as much. Between 1984 and Australia, at 30.9 percent, it was almst enrolled in Australian governmen 2002, the proportion of all students enrolled in Austallandent schools schools fell from 75 percent to 68 percent, the share in independent schools
increased from 6 to 12 percent, and that in Catholic schools remained increased from 20 percent. During this period, enrolments in governmen schools increased by less than 1 percent, the Catholic sector grew by 16 percent and the independent sector by 108 percent (Lamb, Long, and Baldwin, 2004, pp. 16, 40-41). Changes in enrolment patterns were compounded 2004, pp. 16, 40-41). Changes in 2 nolm 2000 there was a 2.7 percen by redirection of funding. Between 1991 and 2000 there was a 2.7 percent increase in private school enrolments as a percentage of all enrolments, but a 4.6 percent increase in government funding for private schools. While the direction of state government funding has changed little, per capita the direction of state governmentent in private schools increased by 94 perCommonwealsh funding per student in private sche in state schools grew by cent between 1991 and 2000; that of per student in state schools grew by 56 percent. Among OECD countries, Australia also has relatively highand increasing - rate of private expendicure on school education (exceeded only by Germany, Mexico, and Korea). Berween 1991 and 2000, while public funding of school education increased by 60.4 percent, private funding-largely from parents of private school students-grew by 95.7 percent (Lamb, Long, and Baldwin, 2004, pp. 12-16).

95.7 percent (Lamb, Long, and Baldwin, 2004, Pp. 12-16).

In Australia, the late 1960 and 1970 s are now considered as the high point of comprehensive high schools and of centrally concrolled and bureaucratically managed public education more generally. University les had been abolished, a national Schools Commission funded a number of innovative equiry and affirmative action programs, and state schools, with around 80 percent of all enrolments, catered to a broad cross-section of the around 80 percent of all enrolments, catered to a during this period drev communiry. The progressive reforms introduced during this

Australian scholars were among those who theorized the ways the "com-

Australian scholars were among chose who here class privilege by converting petitive academic curriculum" helps perpetuate class privilege by convering social background into school results. One of the most influential projos centered around the book Making the Difference, first published in 1982 Drawing on the work of Bourdieu, Bernstein, and others, Connell and his Drawing on the work of Bourdieu, Bernstein, and worklace orientration, and colleagues argued that the forms of solidarity, workplace orientedited a handicap it school. In contrast, the cultural attributes engendered in managers' and professionals' lives were recognized as conceptual sophistication. Corporate and private schools, which could be seen as "organic" parts of the ruling class, played a powerful role in this process. State schools, particularly those in working-class suburbs, had a more tenuous relationship with the families they dealt with. Constrained by university requirements, and frequently despite the best efforts of their staff, they inflicted what could be called "hidden injuries of class" (Sennett and Cobb, 1972) on many of the children they taught. Among these injuries was the children's conviction that they "didn't have the brains" to do any better. Equality of opportunity, in sum, worked betrer for some groups, in some schools and regions, than others. In many demonstrable ways, working-class students and neighborhoods, indigenous Australians, non-English-speaking immigrants, and girls were disadvantaged. The way forward, articulated in a series of influential public reports, was to make schools and their curricula more comprehensive and inclusive.

The recent work of Teese and his colleagues from Melbourne University alls wichin the same broad tradition, bur is written in a considerably different climate. Working in a period of retreat rather than consolidation of comprehensive schools, these scholars focus on the ways government policies and reforms are making schools less comprehensive and democratic. Combining sophisticated, system-wide statistical analyses with powerful theorization of school effects, the authors present compelling evidence that ongoing increases in expenditure targeted at private school students are making large and systematic contributions to social polarization. To some extent, this is because of the sheer disparity in resources between wealchy private schools and ordinary state schools. But the main effect, they argue, is through the differential composition of student groups. Here, the effects of residential segregation are amplified by the capacity of the wealthiest private schools to skim talented and motivated students from their "competitors."

Teese and Polesel (2003) argue that young people prefer curriculum areas where they work in groups, and where results are tangible and valuable in themselves. This is where their efforts have concrete results, which give them confidence in their own ability to transform the world. But doing well in these subjects, however valuable educationally, does not confer a competitive advantage in examinations for university entrance. Subjects such as English, chemistry, machematics, and physics, in contrast, provide intrinsic satisfaction to those that succeed in them, rely on individual effort and responsibility, and revolve around a high degrec of abstraction. In the Australian education system, they are also the most profitable subjects, faciliating entry to faculties preparing students for the most lucrative professions. The minority who do well in such subjects tend to enjoy them; to many, mathematics classrooms resemble a "laboratory where you learn to use tools," or even "a sports ground where you are training to win." Those for whom such subjects are impenetrable tend to experience the most 
prestigious parts of school curricula as boring, and see them in terms of " 2 factory where you are there to work" or an "office where you learn to follow routine." Teese and Polesel (2003, p. 104) note that "learning becomes routine." Teese and Polesel (2003, p. work" for those who least benefir from its outcomes; "the graph of enjoy ment exactly reversed the graph of meaninglessness." While many succeed, they conclude, it is their success relative to those on the other side of town that is significant.

Such arguments are similar to earlier work. What is novel is the authors theorization, based on system-wide statistical analyses of exam results, of the compounding effects of polarized and increasingly competitive educathe compounding effects tion markets. The result, Teese and Polesel show, is the development schools where material and cultural resources and talent are concentrated, and others from which they are drained. By creating a rich pool of cultural and financial resources at selected sites, parents are able to pedagogically multiply individual advantages. The privileged schools tend to have smaller class sizes, berter-trained teachers, more books, computers, and other resources, and students whose social background is more easily converted resources, and students whose soch pooling of resources in private schools into examination success. Such pooling of resources in privace schools "narrows the gap between results for the average child from a background of high socio-economic status and the individual child from such a backhigh socio (2003, p. 121) This works because pedagogical efficiency can be ground." (2003, p. 121) This works because pedagogical efficiency caltural capital, used where new or modest wealth was not accompanied by cultural capital, and also because the challenge of exams could be met collectively, rather failure:

Primare schools, operating on an assured platform of public grants, drain secPrivate schools, operating on an assured platorm of pucation of the cultural resources represented by family education life-style and know-how and pump these into the most profitable locations of the curriculum. (Teese, 2000, p. 204)

On the other side of rown are schools that lack resources, attended by students who pool disadvantage. These increasingly "residual" schook, Teese and Polesel note, cope with poor language skills, fragmented family lives, poverty, low levels of parental education, lack of facilities, high teacher lives, poverty, low levels of parental education, lack of faclities, high the turnover, and leisure that is distracting rather than supportive of school Such schools are hard to staff; they cannot expel disruptive and demandim students, and see many of their most promising pupils transfer out to- -0 r students, and see many of their schools. In one environment, the curriculum outright poached by-private schools. In one environment, the curriculum has been domesticated; in the other, it presents a continual real threat, here many students see the school as a prison, and want to leave to get a job:a soon as they can. Especially among those who get poor results, only soon as they can. Especially among those who get poor resuls, ond, and few girls and fewer boys believe that extra efforts with schoolwork " worthwhile. As other educationist point out, it is by resisting such "baring? work that many children cement their failure in increasingly competitive education markets. As Willis (1977) argued in Learning to Labour, workingclass lads earn self-respect, and the admiration of their peers, by resisting schoolwork in the most imaginative ways they can contrive. Such resistance is fueled by particular notions of sexist masculinity, where physical prowess is admired and bookish learning, pen pushing, and obedience to teachers is despised. In a cruel irony, the lads help produce their class subordination through successful resistance to subordination at school. Similar themes, this time from the perspective of working-class girls, have been developed by feminists writers such as McRobbic $(1978,2000)$ and Hey $(1997)$.

Teese $(2000$, p. 2) provides graphic staristical evidence of the results of this process. In the urban regions of Melbourne where working-class and immigrant families are highly concentrated, every third girl can expect to receive failing grades in the least demanding mathematics subject in the curriculum. Among boys failure strikes more than 40 percent. The better students gravitate to the mathematics subjects that lead to university-but again, one in three fail. This is the same ratc of failure experienced by preparatory mathematics students as a group in 1960. To attend school in the western suburbs of Melbourne, Teese concludes, is to be more than three decades behind in relative terms. To be educated in the upmarket inner east is to leave history behind, for here only 12 percent of boys and 8 percent of girls fail in preparatory mathematics. Similarly, in the dilapidated state schools in the working-class, teindustrializing western suburbs of Melbourne with their many immigrant communities, half or more of all boys fail English. In wealthy private schools, failure in English among boys comes in decimal points or zeros, with 1.2 per 100 an exceptionally high figure (Teese, 2000, pp. 208-09).

At the upper end of the examination register and in areas of the curriculum that count most toward university entry-mathematics and sciences, languages, traditional humanities-high marks again advantage the private system by a large margin. In chemistry, some 30 percent of private school students in Melbourne are placed in the top fifth band of achievement, compared with only 15 percent of public high school candidates. In physics, the margin is 29 percent against 16 percent; in biology 44 percent as against 15 percent; and in specialist mathematics, 28 percent compared with 15 percent. The more culturally selective narure of the students taking subjects such as Australian History and English Literature in private schools is generally associated with even larger relative advantages in performance: private school students are three times as likely as high school students to receive high grades, with every second candidate or more being placed in the top fifth band (Teese, 2000, p. 204). Finally, even though they dominate less prestigious universities and technical colleges, and fewer proportionately complete high school, scudents from state ischools in the western suburbs of Melbourne are three times more likely than private school students to receive no offer at all of a tertiary place at 
the end of their high school study (24 percent compared to 7 percent) (Teese, 2000, p. 211).

Reviewing international comparative data on learning outcomes across a Reviewill areas, Teese and his colleagues note that, on average re results Australian school children achieve are good by internationa the results Australian school children achieve are gased on SES and ocher standards. However, differences in achievement based on SES and ocher social factors are not only larger in Australia than in many OECD counrries, but widen as young people progress through school. The authors contries, but widen as you of a relentless process of segregation, children do not clude that, as a result of a relentless process of segregation, children do not have access to the same resources and learning opportunities. Those who enter private schools are more likely to enroll in the academic track. Those enter private schools are more likelo high school tend to take subjects that are in academic tracks within senior high school tend university and prestigious most profitable in terms of promoting access to university and prestigious courses within universiry. In all, the amplifying power of dissimilar studen courses within universestes in subgroups and their different relationship to curriculum areas resurites. Whilc stancial differences in school success and labor market opportunities. Whivernon-Catholic privare schools achieve, on average, stronger results in universiry entrance examinations, Catholic schools are associared with better sity entrance examinations, in further education and training (Lamb, Rumberger, Jesseon, and Teese, 2004, p. 45).

\section{$* *$ *}

The main emphasis of the work summarized earlier is on system-wide The main extices. In effect, Teese and his coleffects of educational policies and practices. In effect, Teese and his colleagues document a process of making Australian schools less and less comprehensive. In the process, social privilege and disadvantage become prehensive. In the process, to make of findings which show that some amplified. What then are we to make of with modest resources and little cultural capital disproportionarely succeed at school? Italian Australians are a case in point. Nancy, a 45-year-old mother of two teenage children, was born in Melbourne, 45-year-old mother of two teenage children, was born italy. In an interAustralia to parents from the Abruzzo region of southern Italy. In an ined view about families and children I recently conducted, she explained a successful strategy underpinned by hard work, family solidarity, and school success:

I have been married for 25 years and ... my parents have ... always been 1 have been married for 25 years and . my parents have... always been there. ... They've been supportive. They had expectations that we went to uni and that we studied because my parents came here with nothing and they wanted us to achieve.... rock mountains ... and do all the kinds of wanted us to achieve.... . . . had different ideas... I wanted to ... go to uni but $I$ wasn't things ... I had different ideas ... I wanted to ... . . . to be married, have keen on doing that at $18 \ldots$ and I wanted everything ... to be married, have kids, I wanted to have a degree, I wanted to have a career, travel ... And I did all those things ... And my family helped me financially. I bought my first home with my parents' help and in-laws' help. I married an Italian from the same part of Italy. So a lot of things worked out very well for me ... I guess for me there's an expectation-my own-that I'm going to help my children to buy their house ... but I do agree that kids have to learn responsibility and they have to understand the value of money...

Nancy completed a compurer course and now works as an office manager. Her parents identify as Italian, she herself feels Australian, and her children claim they are Italian.

In terms of qualifications, many of Nancy's contemporaries fared less well than she did. Yet recent studies of the comparative standing of different ethnic groups in Australia (Long, Carpenter, and Hayden, 1999) and other English-speaking countries (Zhou, 1997; Waldinger and Perlman, 1998; Boyd and Grieco, 1998) show that children of many poor, badly educated, and exploired immigrants disproportionately succeed at school. Despite coming from lower SES background, a higher proportion of firstgeneration youth born in Asian or southern and eastern European countries complete secondary school and a larger share also continue on to university compared with their Anglo counterparts. A recent national investigation of the Australian-born children of postwar immigrants (Khoo et al., 2002) is a case in point. Based on reanalysis of the 1986,1991 , and 1996 Australian Census, the study made it possible to compare the educational outcomes of several different age cohorts of second-generation Australians. For Italians, the results showed that an earlier pattern of investing in sons' but not daughters' schooling more recently gave way to strong emphasis on the educational qualifications of both genders.

According to the 1996 Census, 23.2 percent of men aged 35-44 with both parents born in Iraly had a degree or diploma, slightly more than thirdgeneration Australians (at 22.5 percent). Another 29 percent of both groups had vocational qualifications. For women, the situation was reversed: 26.5 percent of third-generation Australian women had degrees or diplomas, compared to 22.4 percent of those with an Italian father, and only 18.8 percent of those with both parents born in Italy (Khoo et al., 2002, p. 81). Among botb women and men who attended school a decade or two later, having both parents (rather than just the father) born in Italy now became a marked educational advantage. Among those aged 22-24, 20 percent of second-generation young men and 33.8 percent of women held a degree or a diploma, as opposed to 16.4 percent and 27.9 percent, respectively, for third-generation Australians. Conversely, about 51.5 percent of second-generation Italians had no post school qualifications, considerably fewer than the 57.1 percent of third-generation men and 60.7 percent of women (Khoo et al., 2002, p. 78). There was also far less class-based disparity in educational participation of 20-21-year-old second-generation ttalian Australians than among their third-generation counterparts. Among third-generation men and women, 30.8 percent sons and 40.1 percent 
daughters and of managerial/professional fachers but only 6.7 percent sons and 11.1 percent daughters of those working in "other (mainly unskilled) occuparions" artended university. Among the sons and daughters of Italianborn fachers, the disparity was far smaller: 25.9 percent sons and 36.4 percent of daughters of professional/managerial fathers were university students, compared to 18.2 percent of sons and 21.3 percent of daughters of those in "other occupations" (Khoo et al., 2002, pp. 67, 117). In other of those in "other occupations" (Khoo et al, $2002, \mathrm{PP}, 67$, 117) words, the ratio of what could be called class-based educational inequality
berween third-generation people was about four to one, among second-generarion Italians, considerably less than two to one.

The combined effects of class, ethnicity, and school sector clearly complicate the links between family background and school success. In explaining these figures, three factors stand our: Italian's disproportionate capacity to save and invest in projects they value, the changing fortunes of the Catholic school sector in Australia, and the ability of some ethnic groups to achieve valued outcomes by resisting assimilation.

Escaping postwar shortages, unemployment, and poverty, most Italians came to Australia with "nothing bur their suitcases" to secure a better life for themselves and their children. What they lacked in book learning they made up in shared understandings of the hardship and rewards of establishing a household, or "systemazzione" in distant lands and unfamiliar environments, and assembling a livelihood from a patchwork of low-wage and subsistence activities. Nancy's successful housing strategy is typical of her sure born in Australia of Italian parents between 1952 and 1961, 83.4 percent were living in their own home in 1986, 85.1 percent in 1991 , and 87.5 percent in 1996 . The corresponding figures for third-generation Australians were considerably lower: 63.4, 69.7, and 74.4 percent, respectively (Khoo et al., 2002, p. 78 ). The Italians' capacity to live frugally and to save, some unionist noted, made them more resilient to live frugally and to save, some unionist noted, made them more resilient money," they could undertake more protracted industrial disputes. As two Iralian workers at a large Ford plant in an industrial suburb of Melbourne explained to labor historians (Lever-Tracy and Quinlan, 1988, p. 304) "Australians can't sustain a long strike because they spend each week's wages before they get it. We learned during the war how to survive without food or clothes." "Australians are quick to go on strike but then they want to go back. You don't win that way."

The same capacity to secure a family's future could be mobilized in other ways. Explaining why people like Nancy's children, who often "have to buy nothing" when they marry, decide to have smaller families than their parents, 54-year-old Sandra noted:

It's not that people don't want to have children because it doesn't please them to have children; it is too expensive to have children. You need to send them : to [private] school. You need to dress them. You need to give them sport, exercise, restaurants, all of these things that they want. And if 1 go to work and I don't have enough money to give them all of these things? And so, this is what I think. I have five children, but if I had to have children today, I'd only have two. Maximum three- but no more.

Education assumes particular significance in these calculations. Those who cannot afford private school fees, many grandchildren of Italian immigrants argue, simply should not have kids. As 21-year-old Amanda put it, "You'd want to be able to give them opportunities in terms of school, and ra ra ra. If you can't afford it then ... that's my view anyway. I'd like to send my kid to [private] school and try and give 'em a head start sort of thing.' " A friend added "Yeah, that's pretty much a general kind of view, isn't it?" "No conflicts there," she concluded, after everyone in the group of young adults agreed. In conversations such as these, the assumption that children need to attend private schools is so widely shared that it is not stated.

In their encounters with Australian schools as parents and students in the 1950s and 1960s, most of the Italian Australians I interviewed recalled minor humiliations punctuated by occasions of intense conflict. Those who were able to "pass" pretended to be Anglo-Australian to avoid widespread racism. Pressured by the local Catholic clergy to send children to parish schools, Italian families were less likely than their Australian neighbors to patronize state schools. This hardly constituted a worldly advantage. If anything, the schools' Catholicism was Irish, with little tolerance for nonEnglish speakers. While a few boys' schools run by Catholic brothers and priests established a reputation for success in public examinacions, provision for girls focused on home making, nursing, and teaching (O'Donoghue, $2001)$. Until the 1960 s, Catholic schools received no state aid. Catering to many of the new European immigrants, their enrolments rose sharply in the postwar decades. Although costs were contained with large classes and low pay of teaching congregations, by the late 1960 s the schools faced a crisis: the necessity to employ increasing numbers of lay teachers put most in considerable financial difficulties. When the national Karmel Commirtee reported on schools throughout Australia in 1973, it identified Cacholic schools among those in greatest need and catering to the greatest proportion of disadvantaged students. The Labor Commonwealth Government' adoption of the Committee's recommendation to provide needs-based funding for all Australian schools saved many from closure, and allowed the restoration and expansion of the Catholic system of low-fee secondary schools. Today, the increasing flow of resources toward the private school sector in Auscralia has made attendance of most (not all) Catholic schools a relative advantage rather than disadvantage.

The majority of Catholic schools, catering to a socially more diverse body of students, lack the cultural exclusivity that fuels the pedagogic power of wealthy independent schools. In a scattergram plotting school achievepnent $^{3}$ in the final year of high school against SES in 1998 (Teese and 
Polesel, 2003, p. 120), almost all independent schools lie within the first Polese, 2003, P. 120), almost all independent many are concentrated high up quadrant (high SES and high results), and many are concentrated high in that quadrant. Catholic schools are spread across quadrants ( (low SES, high results), and high results), 3 (low SES, low results), and 4 (low SES, high results), but rend to be more heavily concentrated around the center. Government high schools also display a large spread, but only a few schools are at the high sch of quadrant 1, while a large number are "deep" into quadrant 3.

Wherher or not they have accurate appreciation of the comparative benfirs of particular schools, Iralians are among those leading the flight from che government to nongovernment education sector. In a valuable project che government on the history of compreton document some of the dimensions of this Campbell and Sherington document some policies have different effects in difprocess. Stressing that national school policies have different eaffects in different regions, and for different class and ethnic groups, the authors note that by 2000 , only 38 percent of youth of Souchern European ancestry in NSW attended state schools, as opposed to 66 percent for all Australian (Campbell and Sherington, 2006, p. 141). Of all the groups surveyed, Italians had by far the weakest attachment to state schools and the strongest Italians had by far the weakess. In the inner west region of Sydney, with it attachment to Catholic schools. In the in Carholic schools, children born of strong and long-established system of Catholic schools, children born of Italian mothers were evenly split berween state and Catholic schools in 1976. Twenty years later, the few remaining state comprehensive school 1976. Twenty years later, che few with Italian-born fathers. The vast major only enroled 21 percent of youth with ltalian-born fathers. The vast major ity, 76 percent, attended Catholic schools, and another 3 percent attended other nongovernment schools (Campbell, 2003, p. 590; Campbell and
Sherington, 2006, pp. 144-45). Catering to 76 percent of Italian students, Sherington, 2006, pp. chools were the dominant provider, at a share that Catholic secondary schools were the dominant provid, ar a she the approached the highest level of state school enrolments for all children in the post-World War II period. Children of Greek mothers, in contrast, had the post-World War ll period. Childrachment to stare schools. In 1976, a far greater-but still declining - attachment to strey were enrolled in stare 94 percent of Greek children in this part of Sydr

schools; by 1996 , the proportion was 60 percent. been used as part of an explanation for their modest but still disproporionbeen used as part of an erples. Such considerations of subaltern ethnicity as a ate educational success rates. Surch strength rather than a probioll, like Willis and, initially at least, many of his sociological analyses. Connell, like Willis and, initially at least, many or feminist critics, focused on the dynamics of class and gender but, not ethniciry or race. In the radical education literature of the $1970 \mathrm{~s}$ and $1980 \mathrm{~s}$ working-class immigrants, Aborigines, and people of color were frequenty working-class immigrants, Aborigines, and peopled at once by poverty, bats of familiariry wich school knowledge and customs, sexism and racism; then disadvantage compounded by attendance of impoverished schools. Singo then, a generation of scholars and activists developed compelling critiquo of the ethnocentrism, racism-and empirical shortcomings-of whatien be called a deficit approach to ethnicity. Today, it is routinely acknowledged that "echnic families," despite their poverty, can be a source of strength and resistance in a hoscile Anglo sociery.

Among the most coherent theorization of these issues are accounts of "segmented assimilation," used by a number of North American authors to explain apparcntly anomalous findings regarding the educational attainment of children of immigrants. For many decades, Portes and Zhou (1993) argue, assimilation to the (generally unexamined) norms and values of American society was represented as a good thing. Today, a considerable body of evidence shows that for some groups, the successful avoidance of assimilation, and maintenance of immigrant community cohesion, is a superior path to healch and prosperity. Not only do less "assimilated" immigrants enjoy berrer health status; their children succeed at school against great odds, and at a far greater rate than their more "assimilated" peers. The reasons, according to Portes and Zhou, are relatively straightforward. In impoverished ciry neighborhoods, decimated by deindustrialization, antiegalitarian public policies and racism, young people of color preserve their dignity by developing a vibrant oppositional culture. Like Willis's lads, they oppose school; they also buy and sell drugs, are frequent victims-and perpetrators-of violence, have litcle access to good jobs-and believe, reasonably enough, that there is no point in slaving at school. Newly arrived immigrants who "assimilate" into this oppositional culture become American but fail at school; those who for one reason or another maintain the hopes of their parents and observe the moral norms of a tightly knit ethnic enclave tend to succeed. They devote more time and energy to schoolwork, not least since allegiance to the cultural project of their ethnic communities helps "switch off" resistance to school. Finally, ethnic communities such as the Italians, who for generations perfected strategies for the acquisition of economic security through the pooling of concerted effort of all family members, are well placed to invest in education markets.

Such positive possible effects of ethnicity on educarional outcomes, however, are blocked for children of "socially defined racial minority groups." Mexicans, Chicanos, Dominicans, and Haitians in the United States and Aboriginal children in Australia might well wish to assimilate but find thar normal paths of integration are blocked on the basis of race. Such groups devise alternative strategies of coping with racial barriers. Since they perceive the effects of the education system to be continued exploitation, such strategies are hardly likely to encourage school success (Zhou, 1997, pp. 986-89).

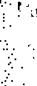
is:

\section{Conclusion}

The retreat from comprehensive high schools, this chapter argued, has gone further in Australia than in most other OECD councries. In analyzing the 
impact of this process, two groups of Australian scholars have developed impace of this process, two groups of approaches that can be of use in other parts of the world. Using sophistcated social theory and extensive survey data, Teese and his colleagues not only provide nuanced descriptions of cultural processes through which eduonly provide nuanced descriptions of culturation, but are able to provide cation markets compound social polarization, but are able to providically innovative unusually detailed, geographically specific, and statistically innovative measures of comparative educational outcomes. In focusing on regional meculiarities of the same broad processes, Camplell and Shcrington show peculiarities of the same broad processes, Camplet andequately studied on the conclusively that education systems cannot be adequately studied on the national level alone. For a range of historical, systemic, and accidental reasons, different regions and social groups negotiate the current

of secondary schools in diverse and often unexpected ways. geographical scale by social demographers and welfare state theorists (Delaney and Leitner, 1997; Mahon, 2005, 2006). Taking as read the premise that and Leitner, 1987, and social actors operate within complex hierarchies of economies, policies, and social actors operate within complex hierarchies of space, these scholars have begun to examine the ways in which notions of scale are socially constructed, and in turn have tangible social effects. Much of the are socially constructed, and in welfare states, with their entrenched scalar literature deals with the way welfare stares, with their entrenched scalar configurations, are being reorganized, rejigged, and retrenched in the current era of global, national, and local restructuring (Brenner, 2001, p. 592). In Austmlian education, a particularly significant aspect of this process concems Australian education, a particularly significant indicators for allocating "needsthe highly contested selection of statistical indicators for allocating "needs based" funding. As Teese (2004) argues, the Commonwealth government applies an "SES methodology" to funding nongovernment schools, which is applies an 'SES mol need and which disproportionately benefits wealthy insensicive to scal need and which disproportion the average income level schools. This is because ir bases definition of need on the average income leve of the statistical districts where individual children reside. This is inequitable, Teese argues, because it does not take into consideration "creaming" school Teese argues, because it does not children enrolled in wealthy independent intake policies, and assumes that children enrolled in wealthy

schools are typical of the immediate locality in which they live.

In education more generally, there are significant, contested, and chang ing configurations of actors, capacitics, and histories at internationali national, and local levels. Regional factors continue to be important; the localities in which schools are built and students reside differ markedly in the extent of residential segregation and social polarization, economic vial the extent of residenta secto ity and wealth. Yet families can and do relocate to other countries, send students to schools in distant suburbs or cities, enroll children in studies for: students to school in dirch the International Baccalaureat out differents provision, curricula, and teaching approaches not only select out different mixice social attributes as marks of intelligence, they assemble quite different mix of students inside classrooms. In this way, they constiture significantly ferent filters for converting social background, financial resources, assiduiḡ ferent filters for converting social background, financial resources, asside and talent into examination results. It is in international projects visible? this book that the dimensions of this process become more clearly visitile

\section{Notes}

1. Under the Australian constitution, the funding of government schools is a state responsibility, but federal governments play an increasing role through per capita subsidies to schools. Both Labor and non-Labor parties are committed to "state aid," with Labor governments supporting greater needs-based funding and Liberal governments being more generous to elite privare schools.

2. The project, funded by a small ARC grant in 2000, involved interviews with 50 grandparents. parents, and children broadly representacive of postwar Italian immigrants in Melbourne.

3. General Achievement Test administered in year 12 in Victoria in 1998.

\section{References}

Boyd, M. and Grieco, E. (1998). Triumphant transitions: Socioeconomic achievements of the second generation in Canada. International Migration Review 32 (4): 853-76.

Brenner, N. (2001). The limits to scale? Methodological reflections on scalar structuration. Progress in Human Geography 25 (4): 591-614.

Campbell, C. (2003). State policy and regional diversity in the provision of secondary education for the youch of Sydney, 1960-2001. Hissory of Education 32 (5): 577-94.

Campbell, C. and Sheringion, G. (2006). The comprehensive public high school: Historical perspectives. New York: Palgrave Macmillan.

Connell, R.W. et al. (1982). Making the difference: Schools, families and social division. Sydney: Allen and Unwin.

Delaney, D. and Leitner, H. (1997). The political construction of scale. Political Geography 16 (2): 93-97.

Hey, V. (1997). The company she keeps: An ethnography of girls friendships. Buckingham: Open University Press.

Karmel, P. (Chair) (1973). Schools in Australia: Report of the interim committee of the Australian schools commission. Canberra: AGPS.

Khoo, S.E., McDonald, P., Giorgas, D., and Birrell, B. (2002). Second generation Australians. Canberra: Australian Centre for Population Research and the Department of Immigration and Multicultural and Indigenous Affairs, AGPS.

lamb, S., Long, M., and Baldwin, G. (2004). Performance of the Australian education and training system. Report for the Victorian Department of Premier and Cabinet, Centre for Post-Compulsory Education and Lifelong Learning, University of Melbourne.

Lemb, S., Rumberger, D.J., and Teese, R. (2004). School performanse in Auseralia: Reruls from analyses of school effectiveness. Report for the Victorian Department of Premier and Cabinet, Centre for Post-Compulsory Education and Lifelong Learning, University of Melbourne.

Ger-Tracy, C. and Quinlan, M. (1988). A divided working class: Ethnic segmentation and industrial conflict in Australia. London: Routledge \& Kegan Paul. 
Long, M., Carpenter, P., and Hayden, M. (1999). Longirudinal surveys of Australian yourb Partioning 1980-1984. Melbourne: Australian Council for Educational Research.

Australian Council for Educational Research. Mahon, R. (2005). Rescaling social reproduction: Childcare in Toronto/Canada (2): 341-57.

(2): 341-57. 457-61.

McRobbie, A (1978). Working class girls and the culture of femininity. In Women's Studies Group, Centre for Contemporary Cultural Studics, Universiry of Birmingham. Women Take Isue. London: Hutchinson.

Birmingham. Women Take lsue. London (2nd ed.). London: Macmillan.

'Donolitic schools in Australia 1922-1965. New York: Peter Lang.

Porres, A and Zhou, M. (1993). The new second generation: Segmented assimilacion and its variants among post-1995 immigrant youth. Annals of the American tion and its variants among post-1995 immigrant youth

Academy of Political and Social Sciences 530: 74-98.

Sennen, $R$ and Universiry Press.

(2004). Submission to senate employment, Workplace relations and education references commitree, inquiry into commonwealth funding for schools.

Tese, R and Polesel, J. (2003). Undemocratic schooling: Equity and quality in mass education in Australia. Melbourne: Melbourne University Press.

Waldinger, R and Perlman, J. (1998). Second generation: Past, present and future. Journal of Ethnic and Migration Studies 24 (1): 5-24.

Willis, P. (1977). Learning to Labour: How working class kids get working class jobx. Westmead: Saxon House.

Zhou, M. (1997). Segmented assimilation: Issues, controversies and recent new research on the new second generation. International Migration Review 31 (4); 975-1008. 
this research, we would argue, would benefit from being based in an understanding of the interrelationships of historical, contemporary, and comparative concerns, developed through combinations of research strategies that highlight individual experience and agency at the same time that they seek out macro-systems and structures. None of this will pick at the bones of the comprehensive high schools; it should rather help us to bring them to life.

\section{References}

Benn, C. and Chitcy, C. (1996). Thirty years on: Is comprehensive education alive and well or struggling to survive? Harmondsworth: Penguin.

Benn C. and Simon, B. (1970). Half way there. Harmondsworth: Penguin.

Conant, J.B. (1959). The American bigh school today: A first report to interested citizens. New York: McGraw-Hill.

Dangerficld, G. (1935/1997). The strange death of liberal England. Stanford: Sanford University Press.

Muller, D., Ringer, F., and Simon, B. (Eds.) (1987). The rise of the modern educational system. Cambridge: Cambridge University Press.

\section{Contributors}

Rene Antrop González is Assistant Professor of Curriculum and Instruction/ Second Language Educarion, University of Wisconsin-Milwaukee.

David Crook is Senior Lecrurer in History of Education and Assistanr Dean of Research and Consultancy at the Institute of Education, University of London.

Anthony De Jesús is Assistant Professor of Social Work, Hunter College School of Social Work, City University of New York.

Barry M. Franklin is Professor of Secondary Education and Adjunct Professor of History at Utah State University.

Gregory Lee is Associate Professor of Policy, Cultural, and Social Studies at the University of Waikato (New Zealand).

Howard Lee is Professor of Educational Studies at Massey University (New Zealand)

Gary McCulloch is Brian Simon Professor of the History of Education and Dean of Research and Consultancy at the Institute of Education, University of London.

Pavla Miller is Professor of Historical Sociology at the Royal Melbourne Institure of Technology University (Australia).

Roger Openshaw is Professor of Educational Studies at Massey University (New Zealand).

Thomas C. Pedroni is Assistant Professor of Social Studies Education and Policy Studies at Oakland University.

Jose $\mathbf{R}$ Rosario is Professor of Educational Foundations and Curriculum and Instruction at Indiana University-Purdue University, Indianapolis.

John L. Rury is Professor of Education at the Universiry of Kansas.

Sevan G. Terzian is Associate Professor and Program Coordinator of Social Roundations of Education at the University of Florida. 